them into laboratories as quickly as possible. BresaGen and ESI also say researchers will be free to patent any invention they develop using the cells. The companies profits will come from commercializing therapies that emerge from the research.

"First options have become the standard," says Mary Ellen Sheridan, associate vice-president for research at the University of Chicago. Researchers and their institutions rarely object because private companies are better able to handle the cost of clinical trials and marketing. And most options expire within a year, after which the researcher can take the invention elsewhere, Sheridan says.

WARF, by contrast, will try to recover its investment by exercising its broad patent rights to human embryonic stem cells. The foundation does not ask for the option to license researchers' inventions, because any company that markets such an invention in the United States will have to pay WARF for a commercial licence to the underlying technology.

But some intellectual-property experts say WARF's patent is so broad it may be challenged in court."When you have a broad patent there is the possibility that broad claims will be held invalid and you will be left with a narrower patent," says Rebecca Eisenberg, a specialist in biotechnology patent law at the University of Michigan.

\title{
Riders on the storm provoke studies of Atlantic dust
}

\section{Rex Dalton, San Diego}

US researchers are planning an extensive study programme following reports that atmospheric dust may be transmitting microorganisms between continents.

Results collated at a workshop held on 14-15 August in Florida will be used as the basis for a grant application to the National Science Foundation early next year, participants say. They hope that the foundation will support the investigation as part of its biocomplexity programme.

Organized by the US Geological Survey (USGS), the workshop brought together 50 scientists from 18 institutions and government agencies.

Participants say recent studies suggest that clay dust from the Sahara desert — particularly from Mali — might be transporting fungi, viruses and chemical contaminants to the Caribbean, the Gulf of Mexico and the southern United States.

For instance, Aspergillus sydowii, which causes disease in Caribbean sea fans, is a possible culprit in the retreat of coral reef in the Caribbean. The fungus has been found in aerosols collected in the Virgin Islands, which are hit by dust storms swept across the Atlantic Ocean from June to October.

Researchers are also studying dust as a cause of the rising number of asthma cases in Barbados and Puerto Rico. Eugene Shinn, a USGS geologist, has even suggested that longrange dust storms could transport the virus that causes foot-and-mouth disease in livestock. He admits there are no data to support this hypothesis, but says that satellite photos from February show a storm sending plumes of African dust over Britain shortly before the outbreak of the disease there.

Ginger Garrison, a marine ecologist at the USGS Center for Coastal Geology in St Petersburg, Florida, says research is planned to analyse dust samples in the mid-Atlantic during storm episodes to compare them with samples from Mali and the Virgin Islands. "We have found quite a load of microorganisms hitchhiking on dust particles across the Atlantic," she says.

The researchers also hope to coordinate with the Asian Pacific Regional Aerosol Characterization Experiment, which has studied dust movements from the Gobi Desert to the western United States.

\section{Japan banks on tissue store for successful drugs}

\section{David Cyranoski, Tokyo}

A Japanese foundation is set to open a major tissue bank by the end of this year, in a move that pharmaceutical companies hope will bolster drug discovery and clinical research in the country.

Researchers agree that Japan needs such a bank to provide ready access to useful tissue samples, and to bring it in line with what is available in the United States and Europe. But some worry that filling the bank will not be easy.

The bank will be run by the Japan Health Sciences Foundation, a governmentaffiliated organization based in Tokyo. Under the plan, tissues including liver, lung and kidney removed during surgery would be stored at a facility in Osaka built by the foundation last year. This would then supply tissue material to both pharmaceutical companies and academic researchers on a non-profit basis.

"The bank will greatly increase research productivity and help companies compete with those overseas," says Kazutaka Ichikawa, senior managing director of the Japan Pharmaceutical Manufacturers Association. Many drug companies already

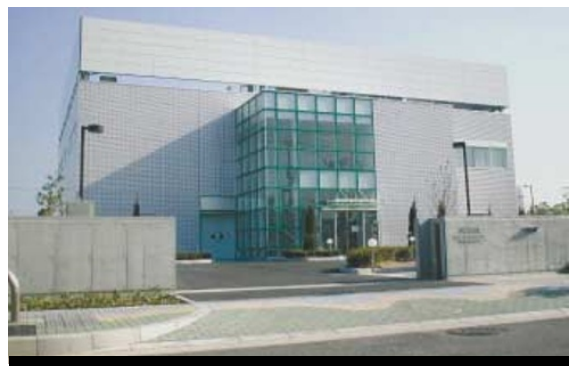

Deposit account: researchers worry that Japan won't find enough donors for its tissue bank.

contribute money to the foundation, which has provided them with cell lines and DNA samples for several years.

An official at the health ministry, which oversees the foundation's activities, says the bank will initially depend on tissue collected from eight hospitals in the Tokyo area.

Researchers will use the tissues to experiment with candidate drugs that have proved effective on animals, but are not yet approved for use in human clinical trials, foundation officials say. "This is standard in the United States and Europe, but it is still immature in Japan," says Tetsuo Sato, chairman of the non-profit Human and
Animal Bridge Discussion Group.

But the tissue bank will only work if doctors can persuade their patients to provide the necessary, explicit consent. A 1996 law forbids the use of organs in research if they were taken from people who only gave consent for them to be used in transplantation.

As a result of the law, human tissue samples are in short supply in Japan, and researchers have to import samples from the United States or rely on overseas partners to do the work.

Ichikawa and others hope that the presence of an official bank and strict enforcement of informed consent guidelines will help to win the confidence of patients and doctors.

But Masanori Fukushima, an epidemiologist at Kyoto University, says that Japan's existing legal framework will make it difficult for the new bank to receive enough donations. "Guidelines on informed consent were only in place since last year and they have no binding power," he says, arguing that clearer laws are needed to punish doctors or researchers who violate patients' rights to privacy and informed consent. 